\title{
Los retos de la Educación Superior en la Comunidad Andina de Naciones
}

PhD. Susana Herrero Olarte Universidad de Las Américas, UDLA susana.herrero@udla.edu.ec Quito, Ecuador https://orcid.org/0000-0003-3509-6316

\section{Editorial}

Para Stampini, Robles, Sáenz, Ibarrarán y Medellín (2015a): los países que pertenecen a la Comunidad Andina de Naciones (CAN), han aumentado en este siglo significativamente el volumen de clase media, en un entorno de crecimiento de la economía nunca experimentado, impulsado por el precio al alza de las materias primas. El gráfico 1, muestra el porcentaje de la población que pertenece a cada clase social.

Gráfico 1. Clase media (\% de la población); en base a Sociómetro-BID.

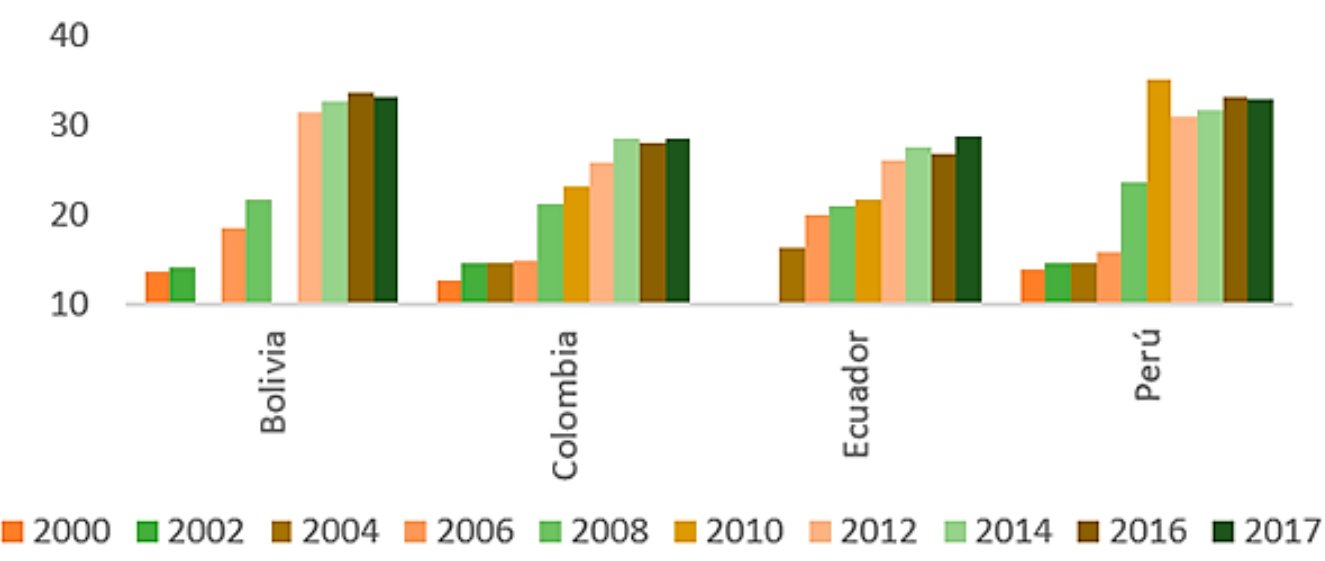

Fuente: La Autora (2019).

De acuerdo con, Stampini, Robles, Sáenz, Ibarrarán y Medellín (2015b): el aumento se da especialmente en los primeros años, y comienza a detenerse desde el año 2012, al empezar a descender el precio de las materias primas. El gráfico 2, recoge la distribución de los ingresos por clase social en promedio para los países de la CAN. El gráfico muestra cómo, a pesar del aumento del 
volumen de personas que pertenecen a la clase media, el grupo en condición de vulnerabilidad es el prioritario en la región. El reto es lograr que las familias en condición de pobreza y vulnerabilidad pasen a engrosar la clase media. Las familias en condición de vulnerabilidad tienen cinco veces más probabilidades que el resto de los grupos sociales de pertenecer durante la siguiente década al estado de pobreza.

Gráfico 2. Distribución de los ingresos (Promedio para los países andinos); en base a Sociómetro-BID.

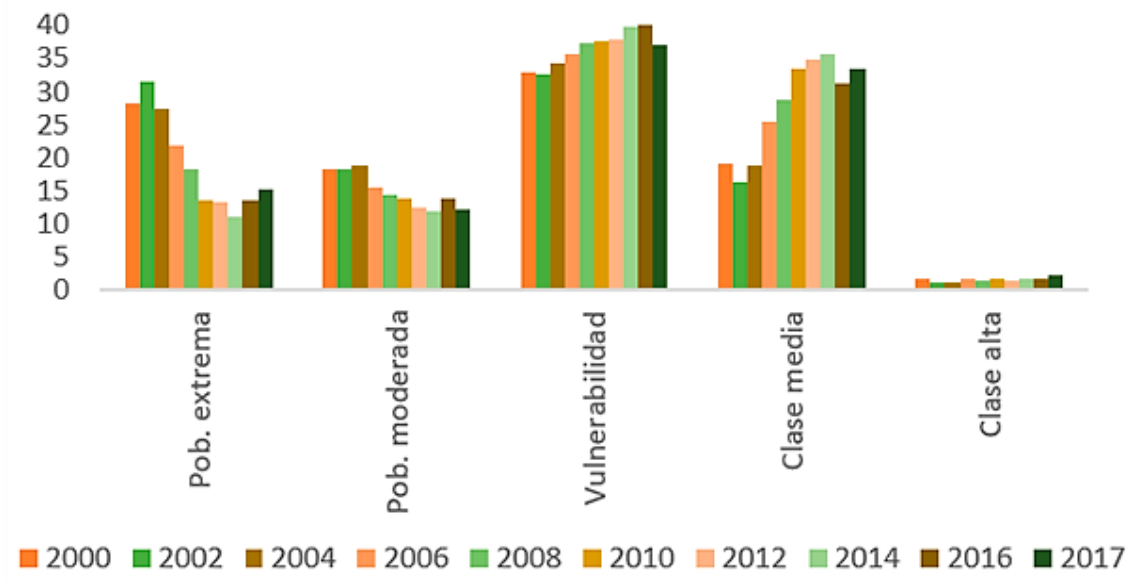

Fuente: La Autora (2019).

En consonancia con López-Calva y Ortiz-Juarez (2014): el temor por perder lo logrado, hasta el momento en la CAN en términos de fortalecimiento de la clase media, y considerando especialmente la variación en las condiciones económicas de la región, invita a plantear estrategias que puedan definitivamente incluir a los grupos en condición de pobreza y vulnerabilidad en la clase media.

En este escenario, y con el objetivo de afianzar estrategias que asienten, protejan e impulsen la clase media, en este sentido Easterly (2001): afirma que la educación superior se erige como un instrumento fundamental al incidir directamente en la persona y posicionarla como actor directamente 
relacionado con la economía, que en conformidad con Willis (2017): permite reducir los límites a la movilidad social que caracterizan las estructuras sociales con significativos porcentajes de la ciudadanía en condición de vulnerabilidad y pobreza.

En este contexto se identifican dos retos fundamentales, como son la participación indígena, muy relacionada con la condición rural, y la mejora de calidad. Toca en adelante abordarlos con políticas directas.

Como presenta Sociómetro-BID (2019): en cuanto a la participación indígena, si bien la cobertura de la educación superior aumentó en 35 puntos desde el año 2000 al 2016, hasta llegar al 52\% de los jóvenes de entre 18 y 23 años, la participación de los grupos étnicos tradicionalmente excluidos es todavía muy limitada. El porcentaje de personas indígenas con estudios superiores pasó del 6\% en el año 2002 al 15\% en el año 2010, pero se redujo hasta el 12\% en el año 2015.

Acorde con esto, Santamaría (2015): manifiesta que de manera general, y a excepción de Bolivia, desde Colombia, Ecuador y Perú, se propone incluir a los grupos indígenas en una estructura pensada por y para la clase dominante, propiciando su desubicación como minoría respecto al total del grupo, tradicionalmente excluida y físicamente alejada.

La alternativa a la estrategia basada en la inclusión total o parcial en el sistema ordinario, son las Instituciones de Enseñanza Superior (IES) exclusivas para los grupos indígenas, propuesta implementada en Bolivia, y planteada de manera menor en el resto de los países. Los resultados de este tipo de propuestas son muy limitados, lo que invita a tener que repensar nuevas estrategias.

En tanto a la calidad, según el QS World University Rankings (2019): entre las diez mejores universidades de la región, dos universidades eran andinas, en concreto colombianas, en el puesto 8 y 9, el 272 y 275 del total. La primera universidad peruana estaba el puesto 551-560 y la primera 
ecuatoriana, en el 701-750. No se recogen en el listado universidades de Bolivia. En tanto a la calificación nacional de cada país, el $15 \%$ de las universidades en Colombia y Ecuador, conforme a fuentes oficiales, se consideran buenas o muy buenas.

Toca en adelante repensar la estrategia de la educación superior para la CAN con vistas a que se pueda incluir a los grupos indígenas y pueda mejorar su calidad, esto de cara a impulsar y sostener, efectivamente, la clase media en la región.

Palabras clave: clase social; educación; educación superior; editorial.

Fecha de Recepción: 17-01-2020
Fecha de Aceptación: 23-03-2020
Fecha de Publicación: 05-05-2020 


\section{The challenges of Higher Education in the Andean Community of Nations}

\section{Editorial}

For Stampini, Robles, Sáenz, Ibarrarán and Medellín (2015a): the countries that belong to the Andean Community of Nations (CAN), have significantly increased the volume of the middle class in this century, in an environment of economic growth never experienced , driven by the rising price of raw materials. Graph 1 shows the percentage of the population that belongs to each social class.

Graph 1. Middle class (\% of population); based on Sociometer-BID.

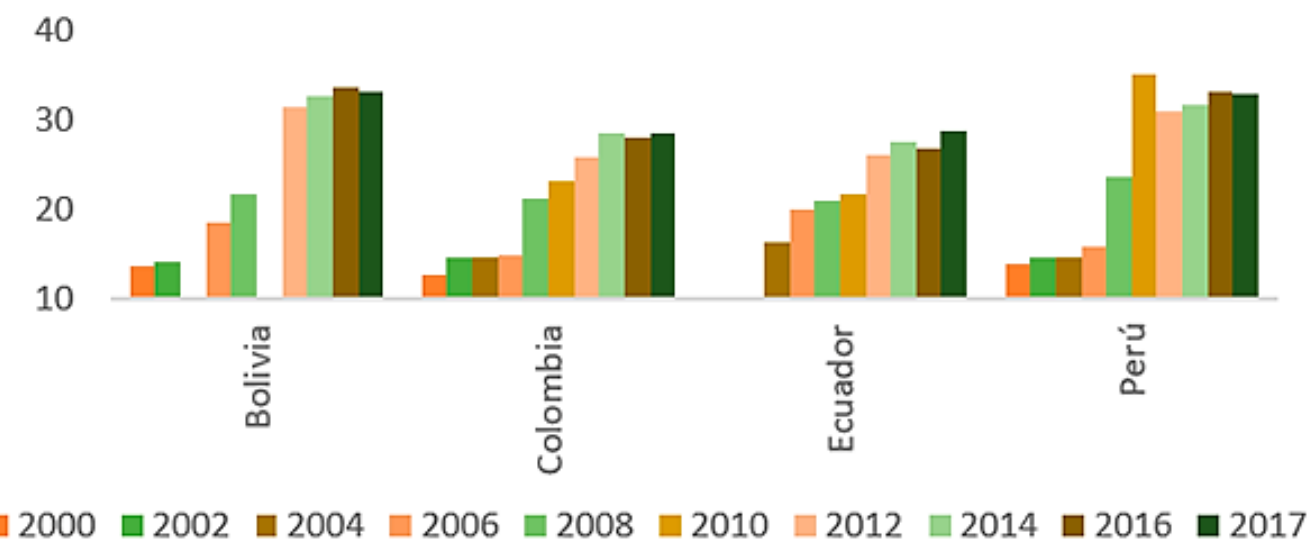

Source: The Author (2019).

According to Stampini, Robles, Sáenz, Ibarrarán and Medellín (2015b): the increase occurs especially in the first years, and it begins to stop since 2012, when the price of raw materials begins to fall. Graph 2 shows the distribution of income by social class on average for the CAN countries. The graph shows how, despite the increase in the volume of people belonging to the middle class, the group in a vulnerable condition is the priority in the region. The challenge is to get families in poverty and vulnerability to grow into the middle class. Vulnerable families are five times more likely than other social groups to belong to the state of poverty during the next decade. 
Graph 2. Income distribution (Average for the Andean countries); based on Sociometer-BID.

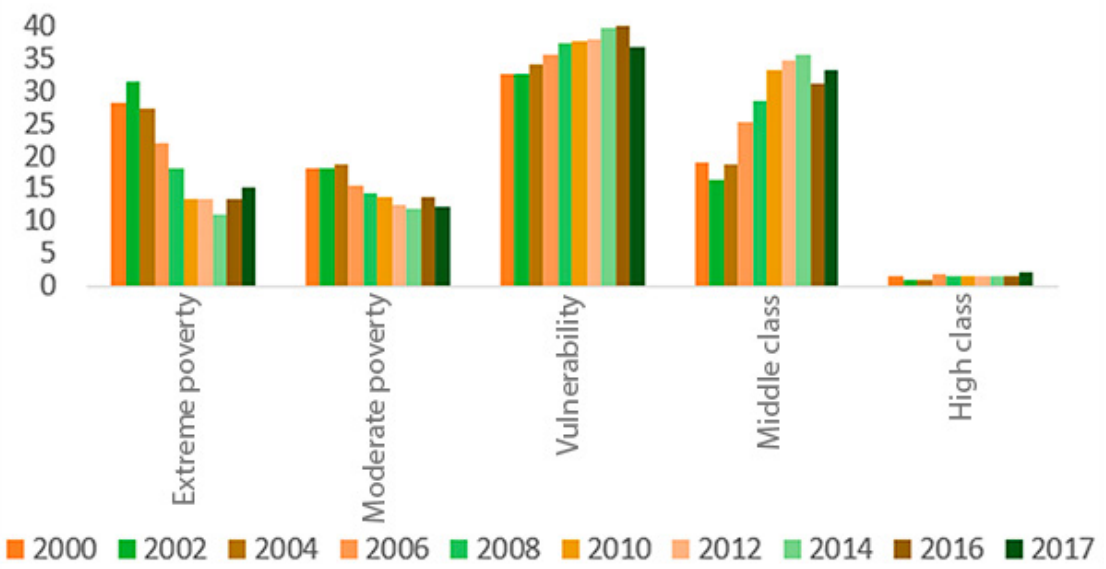
indigenous participation, closely related to rural conditions, and quality improvement. It is now on to address them with direct policies.

As presented by the Sociómetro-BID (2019): regarding indigenous 
participation, although the coverage of higher education increased by 35 points from 2000 to 2016, reaching $52 \%$ of young people between 18 and 23 years old, the participation of traditionally excluded ethnic groups is still very limited. The percentage of indigenous people with higher education went from $6 \%$ in 2002 to $15 \%$ in 2010 , but it decreased to $12 \%$ in 2015 .

In accordance with this, Santamaría (2015): states that in general, and with the exception of Bolivia, from Colombia, Ecuador and Peru, it is proposed to include indigenous groups in a structure designed by and for the ruling class, promoting their displacement as a minority compared to the group as a whole, traditionally excluded and physically distant.

The alternative to the strategy based on total or partial inclusion in the ordinary system is the Higher Education Institutions (IES) exclusively for indigenous groups, a proposal implemented in Bolivia, and proposed less in the rest of the countries. The results of this type of proposal are very limited, which invites us to have to rethink new strategies.

Regarding quality, according to the QS World University Rankings (2019): among the ten best universities in the region, two universities were Andean, specifically Colombian, in 8th and 9th place, 272 and 275 of the total. The first Peruvian university was ranked 551-560 and the first Ecuadorian, at 701-750. Bolivian universities are not included in the list. As for the national rating of each country, $15 \%$ of the universities in Colombia and Ecuador, according to official sources, are considered good or very good.

From now on, it is necessary to rethink the strategy of higher education for the CAN with a view to including indigenous groups and improving their quality, in order to effectively promote and sustain the middle class in the region.

Keywords: social class; education; higher education; publisher.

Date Received: 17-01-2020
Date Acceptance:

23-03-2020
Date Publication:

05-05-2020 


\section{Referencias}

Easterly, W. (2001). The Middle Class Consensus and Economic Development. Journal of Economic Growth, 6, 317-335, ISSN: 13814338, e-ISSN: 1573-7020. Recovered from:

https://doi.org/10.1023/A:1012786330095

López-Calva, L., \& Ortiz-Juarez, E. (2014). A vulnerability approach to the definition of the middle class. The Journal of Economic Inequality, 12, 23-47, ISSN: 1569-1721, e-ISSN: 1573-8701. Recovered from:

https://doi.org/10.1007/s10888-012-9240-5

QS World University Rankings (2019). El ranking de las mejores universidades del mundo. Washington, D.C., United States: PR Newswire: news distribution, targeting and monitoring.

Santamaría, A. (2015). Etnicidad, género y educación superior en Colombia. Trayectorias cruzadas de experiencias interculturales a partir del caso de la Sierra Nevada de Santa Marta, Colombia. Educación Superior y Pueblos Indígenas en América Latina. Contextos y Experiencias, ISBN: 9789871889570 . Colombia: Editorial Eduntref. Sociómetro-BID (2019). Encuestas de Hogares Armonizadas de América Latina y el Caribe. Washington, D.C., Estados Unidos: Banco Interamericano de Desarrollo.

Stampini, M., Robles, M., Sáenz, M., Ibarrarán, P., \& Medellín, N. (2015a,b). Pobreza, vulnerabilidad y la clase media en América Latina. Documento de trabajo del BID: 591, Serie IDB-WP-591. Washington, D.C., Estados Unidos: Banco Interamericano de Desarrollo.

Willis, P. (2017). Learning to Labour: How Working Class Kids Get Working Class Jobs. 1st, ISBN 10: 1857421701, ISBN 13: 9781857421705. London, England: Routledge Publishers. 


\section{Susana Herrero Olarte \\ e-mail: susana.herrero@udla.edu.ec}

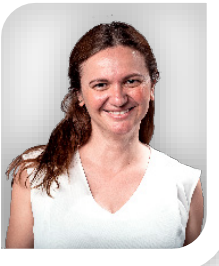

Nacida en Barcelona, España, el 28 de septiembre del año 1981. Doctora en Economía Aplicada de la Universidad Nacional de Educación a Distancia (UNED); Máster en Cooperación y Desarrollo de la Universitat Oberta de Catalunya (UOC); Investigadora y consultora para la UE, Banco Mundial, PNUD, FAO y AECID, en República Dominicana, Haití, México, Guatemala, Colombia, Ecuador, Perú, Malí, Senegal, y Vietnam; Coordinadora de proyectos, investigadora, y docente en el Centro de Investigación y Documentación Europa América Latina (Fundación CIDEAL); Investigadora y docente la Universidad de Las Américas (UDLA); Especialista en economía regional y urbana; he publicado más de 25 artículos, varios libros y capítulos de libros; Catedrática de grado en Sudamérica (macroeconomía) y de postgrado en Europa (economía del desarrollo e historia económica); Durante más de 10 años participé en más de 50 proyectos de investigación y desarrollo con varios organismos multilaterales en América, África y Asia; Actualmente Directora del Centro de Investigaciones Económicas de la (UDLA).

El contenido de este manuscrito se difunde bajo una Licencia de Creative Commons ReconocimientoNoComercial-Compartirlgual 4.0 Internacional 